\title{
Technology and the Human Dimension: Using Web-Based Technology to Develop and Record Generic Capabilities. A Library and Information Studies Case Study
}

\author{
Helen Partridge and Gillian Hallam \\ Queensland University of Technology, Brisbane, Australia
}

\author{
h.partridge@qut.edu.au g.hallam@qut.edu.au
}

\begin{abstract}
The Queensland University of Technology (QUT) is committed to ensuring that its students are not only discipline savvy but also skilled in generic capabilities. To facilitate the development of generic capabilities within its educational programs QUT has supported a project, which involved the creation of a web based tool known as the Student Capability Profile (SCP). The SCP aims to be a dynamic and flexible vehicle for documenting individual student's personal development and growth within the broad spectrum of workplace skills. The SCP will be an invaluable tool, especially in the recruitment process, as it will allow students to inform potential employers of their achievement and growth within generic capabilities. This paper will explore a case study of how the system is being used in teaching generic capabilities such as teamwork and communication skills within library and information studies. The paper discusses the practical implications of using technology to facilitate student deve lopment of generic capabilities and how it impacts on the teaching and learning process.
\end{abstract}

Keywords: genericQ capabilities, library and information studies, IT education, technology and education

\section{Introduction}

In recent years a growing awareness within industry has emerged that the well-rounded professional needs to be not only discipline savvy but skilled in the area of generic capabilities. As an offshoot of this increasing awareness there has emerged a call for higher education to be more actively involved in ensuring that its graduates are developing generic skills. In 1995 Ian Kemp and Liz Seagraves considered the extent to which highe r education can adequately deliver the development of generic capabilities. A survey of staff and students at the Glasgow Caledonian University indicated that there was no doubt that generic capabilities could be delivered by higher education. However, the researchers conclude that if generic capabilities development is to be seriously addressed at universities than a radical rethinking of course curriculum and delivery is required. If institutions of higher education are to continue to meet the needs of its clients, namely students and industry, then it is important that universities actively examine how they can best foster the development of generic capabilities within their students. This paper will explore a web-based system developed at the Queensland University of Technology

Material published as part of these proceedings, either on-line or in print, is copyrighted by Informing Science. Permission to make digital or paper copy of part or all of these works for personal or classroom use is granted without fee provided that the copies are not made or distributed for profit or commercial advantage AND that copies 1) bear this notice in full and 2) give the full citation on the first page. It is permissible to abstract these works so long as credit is given. To copy in all other cases or to republish or to post on a server or to redistribute to lists requires specific permission from the publisher at Publisher@InformingScience.org
(QUT) as a means of developing and documenting students' growth and achievements with generic capabilities. Funded by a QUT Teaching and Learning Small Grant a case study was conducted using students enrolled in the Graduate Diploma in Library and Information Studies. The study examined the potential of the SCP as a vehicle for allowing students to identify, reflect 
upon, develop and document their generic capabilities of teamwork and communication.

\section{Generic Capabilities}

\section{A Definition}

In recent years there has emerged a growing interest within the higher education sector to help students develop life skills that can allow them to "function across different cognitive domains or subject areas and across a variety of social, and in particular employment situations" (Bridges, 1993: 45). Skills such as problem solving, critical thinking, effective communication, teamwork and ethical thinking are all examples of the life skills in question. Together these life skills form the core set of workplace skills and abilities desirable in graduating students and new employees. They complement the discipline specific skills and professional knowledge acquired by students through their university study. Within the literature many synonyms have been used to refer to this core set of skills. Such synonyms include 'transferable skills' (Atlay \& Harris, 2000), 'key competences' (Mayer, 1992) 'generic skills' (Oliver \& McLoughlin, 2001) and 'graduate attributes' (Down, Martin, Hager \& Bricknell, 1999). For the purpose of maintaining consistency within this paper and to link the current work to that being undertaken by QUT in its role as a member of the Australian Technology Network (ATN) (Bowden, Hart, King, Trigwell \& Watts, 2000) the term generic capabilities will be used to refer to these skills and abilities.

\section{Generic Capabilities and Higher Education}

The concept of developing a student's generic capabilities has become increasingly popular in recent years in universities in Australia and overseas. This popularity reflects the increasing interaction that is developing between industry and education. The growing interaction between these two sectors highlights the important role played by higher education as a supplier of employees to the marketplace. For example, in 1996 Gush suggested, "industry occupies a high profile as a stakeholder of higher education and the role and responsibility of higher education is as a provider of graduates to industry". According to Woollard (1995) it is therefore not unreasonable that industry employers should be interested in what graduates know, understand and can do. It is not surprising then that industry groups and professional bodies have begun to strongly advocate the need for universities to offer courses that more adequately meet current industry and marketplace needs. One such area that is being targeted for consideration is that of generic capabilities.

Indeed, findings from a recent poll of employers commissioned by the Department of Education, Training, Youth Affairs (DETYA) (AC Nielson Research Services, 2000) show that employers believe that $75 \%$ of Australian university graduates are not in fact suited for the jobs they apply for. Employers indicate that this apparent lack of preparedness is not in the technical areas but in the generic capabilities of oral and written communication, interpersonal dealings, critical thinking, problem solving and ethics training. The findings of this study suggest that it is imperative that universities develop students who possess not only discipline knowledge but also a high level of personal and interpersonal skills. These findings were not unexpected with many studies over the years throughout the world confirming industry's desire for graduates with generic capabilities and the need for changes to higher education to accommodate these desires (Bennett, Dunne \& Carre, 2000; Dearing, 1997; Dench, 1997; Oliver \& McLoughlin, 2001).

\section{Generic Capabilities at the Queensland University of Technology}

The Queensland University of Technology (QUT) is a member of the Australian Technology Network (ATN), a consortium of technology and industry focused institutions, which includes Curtin University, RMIT University, University of South Australia and the University of Technology Sydney. In 2002 QUT had around 39100 students enrolled, 22600 full time, 12500 part time and 4000 external. The 
university is based around 8 faculties: Built Environment and Engineering, Education, Business, Information Technology, Health, Science, Law and Creative Industries.

QUT is committed to "developing graduates who can contribute effectively as citizens, leaders in the

\section{Knowledge and skills pertinent to a particular discipline or professional area}

Including:

- Coherent theoretical and practical knowledge in at least one discipline area at the level of entry into a profession

- Technological skills appropriate to the discipline.

\section{Critical, creative and analytical thinking, and effective problem solving} Including:

- The ability to critique current paradigms and contribute to intellectual inquiry

- The capacity to exhibit creative as well as analytical ways of thinking about questions in at least one discipline

- The ability to identify, define and solve problems in at least one discipline area.

\section{Effective communication in a variety of contexts and modes}

Including:

- Effective written and oral communication with discipline specialists and non-specialists and in cross-cultural contexts.

\section{The capacity for life-long learning}

Including:

- Searching and critically evaluating information from a variety of sources using effective strategies and appropriate technologies

\section{The ability to work independently and collaboratively}

Including:

- Managing time and prioritizing activities to achieve goals

- Demonstrating the capacity for self-assessment of learning needs and achievements

- Being a cooperative and productive team member or leader

Social and ethical responsibility and an understanding of indigenous and international perspe ctives

Encompassing;

- Active contribution to intellectual, social and cultural activities

- Understanding and appreciation of indigenous perspectives

- Recognition and appreciation of gender, culture and customs of personal and community relations

- Valuing and promoting truth, accuracy, honesty, accountability and the code of practice relevant to the discipline relevant to the discipline or professional area.

\section{Characteristics of self-reliance and leadership}

Including:

- The ability to take the initiative, to embrace innovation, and to manage change productively. 
wider community, and competent professionals within their chosen discipline" (QUT, 2001: para. 1). To this end the university has developed a Graduate Capabilities Policy (QUT, 2001) that guides both students and academics in terms of the generic capabilities that the university seeks to foster in its graduating students. The capabilities are outlined in Table 1.

In collaboration with the ATN, QUT has been involved in an ongoing project designed to foster the development of graduate capabilities within higher education programs (Bowden, Hart, King, Trigwell \& Watts, 2000). As an outcome of this project QUT has developed a web-based tool known as the Student Capabilities Profile (SCP). The SCP is an online approach to the student's professional development. The system aims to be a dynamic, flexible and ongoing vehicle for documenting individual students' personal development and growth across the broad spectrum of workplace skills. The main page of the system is provided in Figure 1.

The SCP will allow students to document and record for later access the experiences and activities that they have undertaken that have helped them to develop as a professional person. The system will allow students to reflect on the generic capabilities that relate to those experience and activities and as a result of this reflection identify their personal strengths and improve upon weaknesses. The SCP will allow teaching staff to be able to see student experiences and engage in a dialog, which can assist with the student's personal development. The teaching staff can set specifically de-

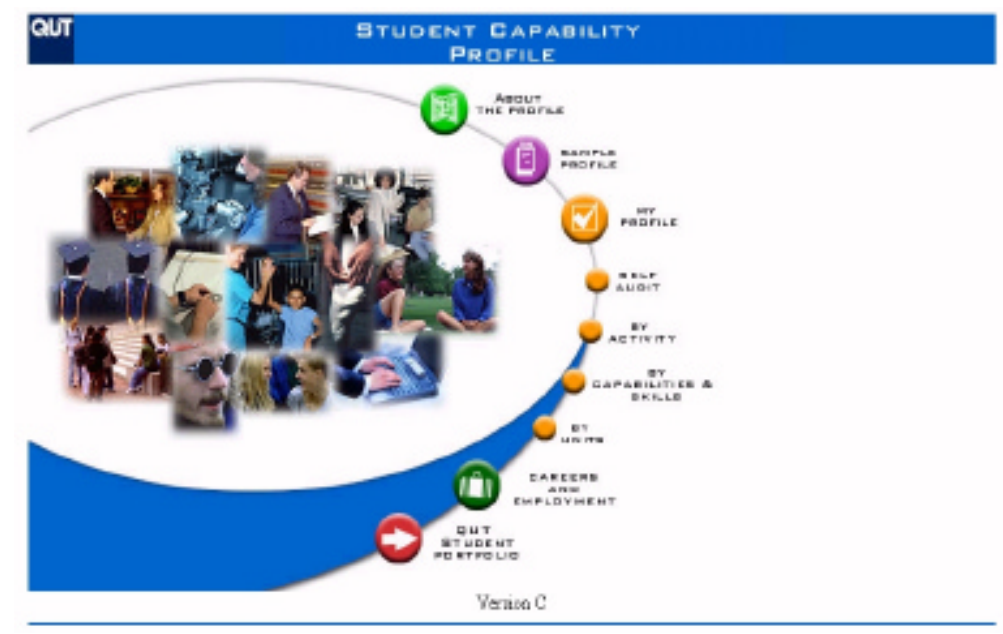

Figure 1. The Students Capability Profile (SCP) signed tasks for students to undertake to develop particular generic capabilities, or students can incorporate relevant experiences or activities undertaken outside of the academic environment. The progressive development of the range of capabilities throughout the student's university studies is collated within the SCP to create an individual personal profile.

The SCP is itself in a stage of development and refinement. It has been the center of a small but growing number of teaching and learning projects at QUT endeavoring to explore its many features for relevancy within specific disciplines. Under a QUT policy teaching staff are encouraged to "review the use of the SCP to document activities in courses and units which develop generic capabilities and encourage students to use the SCP to systematically record and reflect upon learning experiences and activities that illustrate their development of generic skills at QUT" (QUT, 2001: para. 12). Feedback from these projects will aid in the development of the second stage of the system.

One of the major benefits of the SCP rests in the way in which the system can be used by students within the full spectrum of academic units in their course of study at QUT to record the individual student's own development of their generic capabilities. The student's personal profile therefore grows and evolves as the student grows and evolves, thus becoming a living collection of references and evidence.

This personal profile created by the SCP will be an invaluable tool for the student, especially in the recruitment process, as it will allow student to demonstrate to potential employers their achievement and growth within generic capabilities. According to Hargreaves, Murray and Allison (2001) the "SCP will provide employers with a more holistic view of potential employees" (para. 1). The employer can become aware "not only of technical competence from the academic transcript but also of the generic ca- 
pabilities of the student" (Hargreaves, Murray \& Allison, 2001: para. 14). The student can gain further value of the SCP as an Alumnus of the university. As the graduate progresses through the different stages of their career, they can continue to add to the system in order to communicate to current and potential employers their experience and competencies.

\section{The Case Study}

\section{Graduate Diploma in Library and Information Studies}

The Graduate Diploma in Library and Information Studies (GDLIS) is a course offered via the School of Information Systems within the Faculty of Information Technology. It consists of seven core academic units and one elective unit. The course is completed in one-year full time or two years part time. The GDLIS is aimed at providing students with the theoretical and practical skills needed to identify, select, assemble and disseminate information resources to meet the information needs of others. On completion of the course students will be eligible for professional membership of the Australian Library and Information Association (ALIA). In 2002 there were 89 students enrolled in the course, 61 part-time and 28 full-time.

\section{ITN336 Information Sources}

ITN336 Information Sources is a core unit undertaken during semester 1 of the GDLIS. The unit introduces students to the field of reference work in libraries and information centres. The curriculum aims to cover information retrieval techniques, the role of the reference and information service in libraries, the development of digital reference services and the impact of technology of reference collections and services. In Semester 12002 there were 51 students enrolled in the unit, 22 part time and 29 full time.

\section{Which Generic Capabilities?}

The two generic capabilities of teamwork and communication were identified in the QUT list of capabilities (see Table 1) as being central to the ITN336 teaching and learning objectives. Successful professionals in the field of reference and information work must possess both excellent communication and teamwork skills (De Vries \& Rodkewich, 1997; Katz, 2002). For the purposes of clearly guiding the student's understanding of these two capabilities and their relevance to the unit detailed descriptions of each were developed:

- Teamwork is the ability to work with others in a group with the view to achieving defined goals. Two distinct roles necessary for teamwork are the team member and the team leader. A team member makes a productive contribution to the collaborative effort of the group by participating in the pursuit of group goals under the guidance of the team leader. The team leader makes a productive contribution to the collaborative efforts of the group by providing guidance to ensure desired goals are met.

- Communication is the ability to exchange feelings, ideas and information with others in an appropriate manner. Communication consists of the two key aspects of oral and written skills. Oral communication involves using the human voice to effectively articulate a message to an intended audience. Written communication involves using text or graphics to effectively transmit a message to an intended aud ience.

\section{The Issues}

The students enrolled in ITN336 are not a homogeneous group. The students represent a wide diversity of differences including gender, personal interests, employment history, academic background and life experiences. Such diversity has significant implications for staff who aim to foster the individual devel- 
opment of generic capabilities. As each student is at a different stage in their personal and professional lives they will all have their own understanding of the immediate academic context, and will have disparate perceptions and experiences in terms of developing generic capabilities. In order to accommodate such diversity a number of strategies have been put into place, which would essentially value the differences in student personality and backgrounds and help all students maximize the opportunity to develop their generic capabilities. These strategies included:

- Adoption of a team teaching approach to the unit to allow for students to have access to different teaching styles and to ensure a greater level of individual support.

- Modification of the unit's teaching methods to more readily embrace the diversity within the student body, e.g. students were provided the opportunity to engage in group activities and to communicate freely with each other, specifically within learning sessions that allowed individuals within the group to share and comment on their own experiences.

- Changes to the assessment methods to incorporate greater flexibility and to allow for individual preferences in approaches to learning.

- Introduction of reflective practice to enable students to consciously be aware of their learning experiences and their own personal development as a result of completing each assessment item.

It was particularly important to effectively incorporate these teaching and learning approaches into the curriculum to ensure acceptance by the students.

\section{Embedding the Generic Capabilities into the Curriculum}

One of the principal challenges for academic staff was, in fact, to determine how to seamlessly integrate the construct of generic capabilities into the traditional curriculum, both within the classroom context and the assessment practices. The QUT teaching semester is only 13 weeks in duration, it is therefore also important that generic capabilities are incorporated in to the unit's teaching schedule in such as way that both generic capabilities and discipline content receive the appropriate balance of time, resources and focus.

The framework developed by Oliver (1999) (and later modified by Luca, Oliver, Omari and Dunbar (2001)) was used as the basis for promoting the development of generic capabilities within the unit. According to Oliver, the successful development of generic capabilities within an online environment consists of a finely developed relationship between assessment, learning activities, learning supports and learning resources (Figure 2). In this relationship assessment is "instrumental to the whole design process and is considered in each element of the framework"

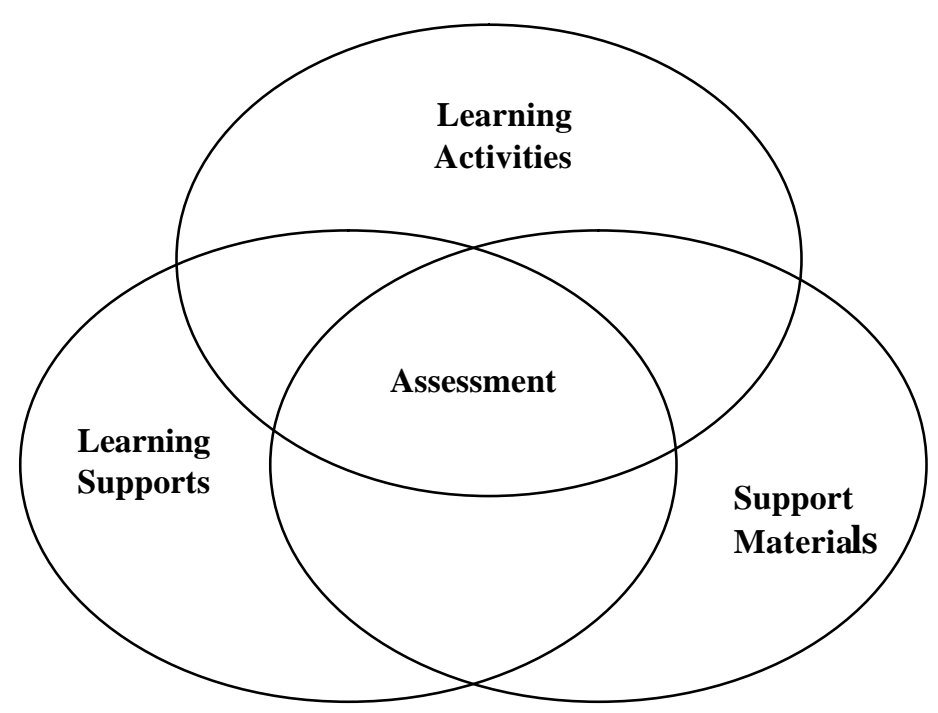


(Luca, Oliver, Omari \& Dunbar, 2001: 11-1). Learning activities should be designed to "promote authentic context, self regulation and reflection" (Luca, Oliver, Omari \& Dunbar, 2001: 11-2). Learning supports are designed to assist the student and to provide constructive feedback on their progress. Support materials in print and online form provide help to the students during their progress.

\section{Teaching Generic Capabilities and the SCP}

To assist the students in the process of identifying and developing their teamwork and communication skills within the given discipline context, the unit's teaching schedule was adapted to include several discrete learning activities. Based on the framework developed by Oliver, the activities were designed to promote an authentic learning context (i.e. to learn about teamwork they were required to work in teams), self-regulation (i.e. the student is in control of their learning experience) and reflection (i.e. individual and group reflective discussions). The activities were designed to foster a collaborative learning environment, whereby students could support each other through the learning process. The unit's teach-

\begin{tabular}{|c|c|}
\hline Activity & Generic Capabilities/Skills \\
\hline $\begin{array}{l}\text { Activity Title: Introduction } \\
\text { Week: } 1 \\
\text { Duration: } 1 \text { hour } \\
\text { Summary: As part of the overall introduction to the unit } \\
\text { the students were introduced to the idea of generic capa- } \\
\text { bilities and were asked to discuss how they view and value } \\
\text { generic capabilities. Students were encouraged to reflect } \\
\text { upon their own generic capabilities in their own personal } \\
\text { and professional lives. Students were given the opportunity } \\
\text { to discuss the process of developing generic capabilities in } \\
\text { general. }\end{array}$ & Generic Capabilities in general \\
\hline $\begin{array}{l}\text { Activity Title: How to prepare and present a literature re- } \\
\text { view } \\
\text { Week: } 3 \\
\text { Duration: } 1 \text { hour } \\
\text { Summary: An open class discussion was held. Students } \\
\text { reflected upon what is a literature review and what are the } \\
\text { steps to successfully developing one. }\end{array}$ & Communication/Written Communication \\
\hline $\begin{array}{l}\text { Activity Title: Teamwork Skills } \\
\text { Week: } 4 \\
\text { Duration: } 1 \text { hour } \\
\text { Summary: Students in groups of } 4 \text { or } 5 \text { were asked to } \\
\text { identify the seven deadly sins of teamwork and together } \\
\text { reflect upon 'good' or 'desirable' teamwork skills. }\end{array}$ & $\begin{array}{l}\text { Teamwork/Team Member } \\
\text { Teamwork/Team Leader }\end{array}$ \\
\hline $\begin{array}{l}\text { Activity Title: The Reference Interview \& } \\
\text { Effective Presentation Skills } \\
\text { Week: } 8 \\
\text { Duration: } 2 \text { hour } \\
\text { Summary: Students in groups of } 3 \text { performed mock refer- } \\
\text { ence interviews. In groups of } 4 \text { or } 5 \text { students were to iden- } \\
\text { tify and reflect upon the characteristics of oral presenta- } \\
\text { tions which receive a High Grade, a Medium Grade and a } \\
\text { Low Grade. }\end{array}$ & Communication/Oral Communication \\
\hline
\end{tabular}

Table 2: Generic Capabilities Teaching Sessions 
ing team provided the students with learning support during the activities by fostering a safe and nonthreatening learning environment and by guiding the students through the process and offering regular constructive comment and feedback. A brief outline of each learning activity is included in Table 2.

The online teaching (OLT) web site was established to act as the key support material in the unit. The OLT site provided students access to information and materials that would assist them in undertaking the learning activities and in developing their teamwork and communication skills in general. The web site provided access to all materials used in the learning activities, recommended readings, useful resources on teamwork and communication, plus general unit information including the unit outline and the assignment sheet. The site also provided students access to an online discussion forum through which they could communicate freely with others in the unit without the restrictions of time and distance. Students could contribute to the learning community by adding the details of any interesting or relevant materials they found during the course of the semester via a Student Recommendations Bulleting Board.

Students were given detailed instructions on how to use the SCP as this system was to be used for the submission of certain pieces of assessment. These instructions were imparted in a computer laboratory through a 20-minute presentation, with further time for questions and answers. The instructions were placed on the unit's OLT web site for students to access.

\section{The Assessment}

The assessment for ITN336 was revised to more directly embed the two generic capabilities into the teaching and learning objectives. In addition, the assessment tasks were modified to incorporate the SCP as a tool used by the students to identify, record and reflect upon their development of skills within the two generic capabilities.

Students were asked to complete four pieces of assessment. As suggested by Oliver the assessment is instrument to the whole process designed, and as such was developed first. All learning activities, learning supports and learning materials were developed to feed directly into the assessment. The major change made to the unit's assessment included an introduction of two linked pieces of assessment: a literature review and a reference service review. Students were required in small groups of no more than 3 to complete both tasks. These assessment tasks were designed to allow students firstly, to develop their research skills by engaging with the current literature within the discipline and secondly, to interact and experience current industry practice. The tasks were also designed to encourage the students to explore their personal experiences with developing good communication and teamwork skills. A brief outline of each assessment item is provided in Table 3.

A further feature of the assessment was the scope for individualization, whereby students could determine the specific context of reference and information services they wished to review. This enables students to tailor their study to specific areas of interest or possible career paths, choosing to focus primarily, for example, on public libraries or law libraries, or to select specific issues confronting reference services, which they find particularly interesting, and to examine these in greater depth.

The flexibility inherent in this approach to assessment supports the views that the concept of 'sensemaking' is central to the ability of individuals to construct their learning: students need to pull together theory, practice and, importantly, prior experience to create new knowledge. Who you are and what you have experienced in the past will affect the way you interact with the new elements of information along the data-information-knowledge creation chain. In this way, every individual student, each with a different background, culture, values and experiences, becomes a dynamic creator of meaning in the learning process. The students were asked to reflect on their learning, on their teamwork skills and the development of their communication skills, submitting their reflections via the SCP for feedback. 


\begin{tabular}{|c|c|}
\hline Assessment Item & Generic Capabilities/Skill \\
\hline $\begin{array}{l}\text { Assessment 1: Literature Review } \\
\text { To Be Conducted: In small groups } \\
\text { Weighting: 35\% } \\
\text { Summary: Students are required in teams to write a } \\
\text { 3000-word literature review that demonstrates their un- } \\
\text { derstanding of the current challenges and issues in pro- } \\
\text { viding a Reference and Information Service. Each } \\
\text { group will submit a Literature Review Structure via the } \\
\text { SCP and the Literature Review in hard copy. All stu- } \\
\text { dents will submit a Reflective Discussion via the SCP. } \\
\text { Submission Method: SCP + IT Resource Center }\end{array}$ & $\begin{array}{l}\text { Communication /Written Communication } \\
\text { Teamwork /Team Member }\end{array}$ \\
\hline $\begin{array}{l}\text { Assessment 2: Reference Service Review } \\
\text { To Be Conducted: Same groups as in Assessment } 1 \text {. } \\
\text { Weighting: } 35 \% \\
\text { Summary: Students are required in teams to review and } \\
\text { evaluate an existing Reference and Information Service } \\
\text { of their own choosing. A } 2500 \text { written report is to be } \\
\text { completed and submitted in hard copy. All students } \\
\text { will submit a Reflective Discussion via the SCP. } \\
\text { Submission Method: SCP_ IT Resources Center }\end{array}$ & $\begin{array}{l}\text { Communication/Written Communication } \\
\text { Teamwork/Team Members }\end{array}$ \\
\hline $\begin{array}{l}\text { Assignment 3: Reference Queries } \\
\text { To Be Conducted: Individually } \\
\text { Weighting: } 20 \% \\
\text { Summary: Each student will individually respond to } \\
40 \text { mock ready reference queries. A written response } \\
\text { will be submitted via the SCP. } \\
\text { Submission Method: SCP }\end{array}$ & Communication/Written \\
\hline $\begin{array}{l}\text { Assignment 4: Reference Tool Evaluation } \\
\text { To Be Conducted: Individually } \\
\text { Weighting: } 10 \% \\
\text { Summary: Each student will individually select and } \\
\text { evaluate } 1 \text { ready reference tool. Each student will give } \\
\text { a 5-minute presentation on the tool and provide a writ- } \\
\text { ten } 1000 \text { report in hard copy. } \\
\text { Submission Method: IT Resource Center + Class Pres- } \\
\text { entation }\end{array}$ & $\begin{array}{l}\text { Communication/Written Communication } \\
\text { Communication/Oral Communication }\end{array}$ \\
\hline
\end{tabular}

Table 3: ITN336 Assessment Items Semester 12002

\section{The Role of the SCP}

The SCP system was incorporated into the teaching and learning program of the unit to provide the underlying mechanism by which students could record their experience and monitor the development of the communication and teamwork skills being explored within the unit. On completion of the unit the students will have a documented path of their growth in both capabilities, which they can add to during the course of their studies, and even beyond their studies during their later employment within industry. Accordingly, the system will provide the means by which the students can demonstrate to potential employers their competence in the skills of communication and teamwork. 


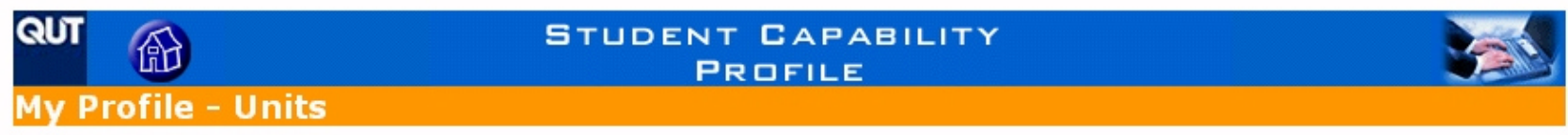

Activities I Capability | Units

ITN336 Semester 1, $2002=$

\begin{tabular}{|c|c|c|c|c|c|}
\hline Capability & Skill & Skill Levels & Skill Level Descriptions & Link to Relevant Activities & Status \\
\hline \multirow[t]{2}{*}{$\begin{array}{l}\text { Team work } \\
\text { (ITN336) }\end{array}$} & \multirow[t]{2}{*}{$\begin{array}{l}\text { Team member } \\
\text { (ITN336 Unit) }\end{array}$} & \multirow[t]{2}{*}{ (L1) } & & $\begin{array}{l}\text { Assignment 1: Literature Review Structure } \\
\text { Assessment }\end{array}$ & $\begin{array}{l}\text { Overdue } \\
28 \text { Mar } 2002\end{array}$ \\
\hline & & & & $\begin{array}{l}\text { Assignment 2: Reflection on teamwork skills } \\
\text { Assessment }\end{array}$ & $\begin{array}{l}\text { Overdue } \\
31 \text { May } 2002\end{array}$ \\
\hline \multirow[t]{4}{*}{$\begin{array}{l}\text { Communication } \\
\text { (ITN336) }\end{array}$} & \multirow[t]{4}{*}{$\begin{array}{l}\text { Written communication } \\
\text { (ITN336 Unit) }\end{array}$} & \multirow[t]{4}{*}{ (L1) } & & $\begin{array}{l}\text { Assignment 1: Literature Review Structure } \\
\text { Assessment }\end{array}$ & $\begin{array}{l}\text { Overdue } \\
28 \text { Mar } 2002\end{array}$ \\
\hline & & & & $\begin{array}{l}\text { Assignment 1: Reflective Discussion } \\
\text { Assessment }\end{array}$ & $\begin{array}{l}\text { Overdue } \\
26 \text { Apr } 2002\end{array}$ \\
\hline & & & & $\begin{array}{l}\text { Assignment 3: Reference Queries } \\
\text { Assessment }\end{array}$ & $\begin{array}{l}\text { Overdue } \\
10 \text { May } 2002\end{array}$ \\
\hline & & & & $\frac{\text { Database creation }}{\text { Extra-curricular }}$ & Unverified \\
\hline
\end{tabular}

Figure 3: An Example Student Profile

The SCP is designed in such a way that students, through their own personal profile, can easily view the generic capabilities that they are developing within the unit and the associated assessment tasks (or activities) that will aid their development. The system allows the student to view what activities they have across all units that they are enrolled, for a specific unit, or for a specific capability. A sample page from a student's personal profile is provided in Figure 3.

An Activity page is provided for each assessment task or activity that the student is to complete using the SCP. The Activity page outlines the activities requirements, due date and provides a listing of the generic capabilities that the task is encouraging the student to develop. It is through this Activity page that the student is required to submit parts of their assessment tasks. Figure 4 presents a sample web Activity page.

\section{The Evaluation}

A number of evaluation strategies were used to assess the effectiveness of the teaching, learning and assessment approaches used within the unit and of the SCP in helping students develop their teamwork and communication skills. These included:

1. Ongoing Adhoc Feedback: Students were encouraged to engage in an open dialog with the researchers on their dealings with the SCP and with the generic capabilities in general. In particular, when students

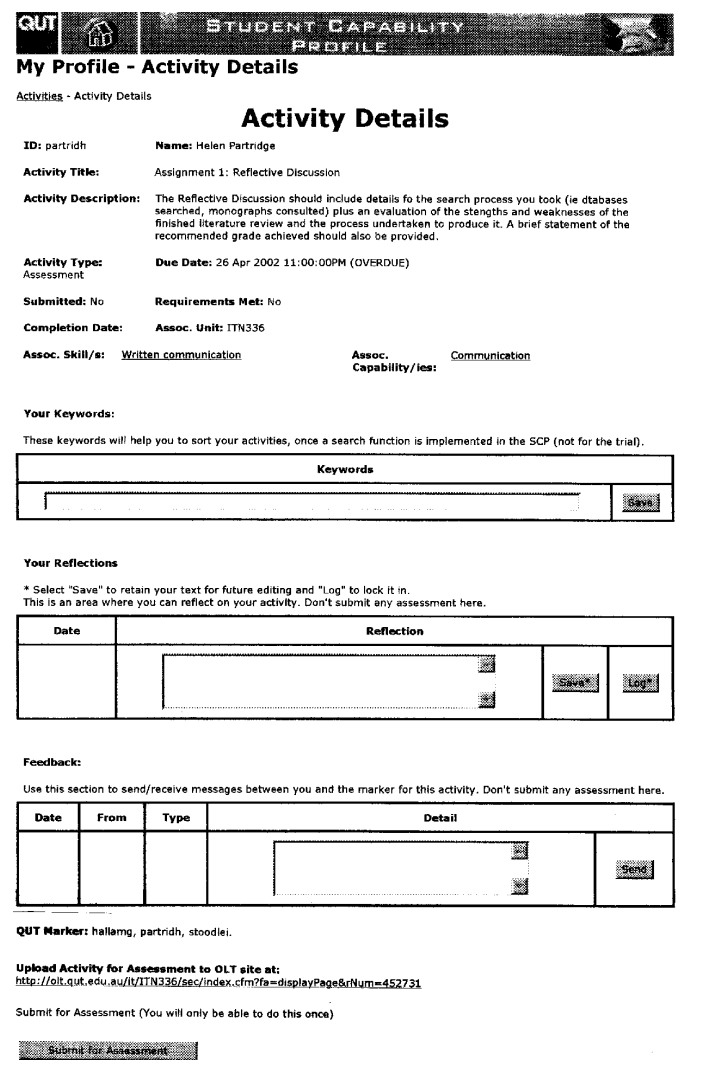

Figure 4: An Example SCP Activity Page 
submitted each piece of assessment via the SCP they were asked to include a commentary on their experiences with the SCP. Whilst this was an optional task, many of the students were more than happy to provide their views.

2. Formal Feedback: Student feedback was formally obtained via small group discussions and individual surveys in Week 14. The survey was developed by the teaching team to determine the success of the SCP in meeting its stated objective of being a tool to help students identify, develop, reflect upon and document their experience with generic capabilities. The teaching team was also interested in establishing a profile of the student's experience in developing generic capabilities within the unit in general. Quantitative data was obtained by asking students to indicate if they agreed or disagreed to a series of statements about their experiences in developing generic capabilities with the SCP and the unit on a 5 point Likert scale. A number of open questions were included to encourage students to respond freely about their experiences. Students were told that results would be completely anonymous and confidential and that their involvement in the survey would not impact upon their results in the unit.

3. Informal Review: The unit's teaching team met regularly to discuss their experiences in using the SCP and in embedding the generic capabilities into the unit. These sessions were an informal avenue of keeping track of the current situation and any arising problems.

37 out of the 51 student's enrolled in the unit completed a formal review process in Week 14 of semester. Students were asked to consider how well the unit and the SCP allowed the student to identify, reflect upon, develop and document their communication and teamwork skills. The four areas examined within the review, namely identify, reflect upon, develop and document, were chosen because they had been defined as the key areas of functionality for the SCP. Consequently, it was important to determine how effectively the system successfully performed in these areas. In addition, these areas were considered in reviewing the unit's effectiveness in the teaching of generic capabilities as a whole. Table 4 provides a summary of the results obtained from the review of the SCP and the unit's relationship to the two generic capabilities.

On the whole the results suggest that the students remained unconvinced about the SCP's ability to help with identifying, reflecting upon, developing and documenting the students experience with both communication and teamwork skills. The overall average responses ranged from 2.38 to 2.75 . The highest average response to the SCP was obtained in relation to its ability to assist students in reflecting upon their communication (2.75) and teamwork skills (2.75). Since a score greater than 3.0 can be viewed as a positive response the results suggest that the SCP as a tool designed to aid students with the development of generic capabilities appears to have been unsuccessful. For example, one student stated that, “the SCP [didn't] provide any particular support [in terms of] communication skills - it was no different to reflecting and documenting in a Word file or journal and handing it in".

When asked whether the SCP achieved its stated aim of "providing support [to] you in developing your generic capabilities and helping you to reflect on your strengths and weaknesses across life's experiences", nearly half of the students surveyed disagreed. A similar number of students indicated hat they would not be interested in using the SCP in another unit. It is important to note here that the experience of the students with regard to the SCP was in part determined by the manner in which the SCP was incorporated into the unit by the teaching staff and this will have an impact on the student's perceptions of the SCP as a whole and their desire to use it in other units.

Students further commented that the flexible 24-hour off-campus assignment submission method was the primary strength of the system. The major weakness of the SCP was the failure of the system to work properly due to technical problems. It was also noted that the SCP was regarded as yet another online tool that the students needed to utilise within the unit. Students frequently commented that greater cohesion between the unit's online teaching web site and the SCP would have been more benefi- 
cial. As the system currently stands, the student need to initially use the online teaching site to obtain the full details of each assessment task, but then must use the SCP to submit the actual pieces of assessment. The process is viewed as cumbersome and non-intuitive.

From the perspective of the administration of the SCP by unit teaching staff, the primary limitation of the system was the considerable time required by the teaching team to create and maintain these two nonintegrated web sites.

Feedback on the unit's impact on students in developing generic capabilities was also obtained. On the whole the results suggest that the unit is perceived by students to be of some value as a means of helping to identify, reflect upon, develop and document the students experience with both communication and teamwork skills. The overall average responses ranged from 3.32 to 4.14 . The ability of the unit to assist students in identifying and reflecting upon their teamwork was ranked the highest. Student comments [grdupe ofthe tssioghgnenps work] non-communication [i.e. as a discipline of study] students some more chances to see their strengths and weaknesses in the context of...communication" and "it is good to focus on teamwork as it gives the impression that [it] can always be improved".

\section{Discussion}

The results of the project indicate that, overall, there has been a favourable response on the part of the students to the concept of developing generic capabilities within the unit. Detailed discussion with students throughout the semester highlighted their growing awareness of the significance of generic capabilities for graduates, that employers were actively seeking employees with more than the core discipline skills, and that personal and interpersonal skills and attributes were overtly sought in position descriptions and selection criteria for jobs.

Results from the current research project indicate that ITN336 does contribute to the student's development of the specific generic capabilities of communication and teamwork skills. The results also show, however, that the SCP, whilst seen conceptually as a valuable enabling tool, was not yet achieving its 
intended goal to support the student in their recording and monitoring of the development of these capabilities. The shortcomings of the system at the functional level means that, in its present form, the SCP cannot yet be used to develop the desired electronic portfolio which could be of so much value to students as they embark on their new careers. The system was also quite time consuming and cumbersome for the teaching team to administer and maintain. The system would benefit greatly by improvements that would allow it to become a more dynamic and interactive environment and that will allow the system to more smoothly function with pre-existing teaching resources such as the unit's OLT web site. This case study with the SCP is one of several that are taking place at QUT. To help refine and further the develop this system, the key findings from this study will be discussed with the SCP creators.

\section{Conclusion}

While the project described in this paper focused on the development of two specific generic capabilities within the context of the one academic unit ITN336 Information Sources, it should be noted that the conceptual work continued in the subsequent semester within one other of the GDLIS core units, specifically in ITN339 Professional Practice. In this unit, students undertake fieldwork and develop their first professional portfolio. These activities helped the students focus more directly on the value of developing generic capabilities and on their relevance to their future careers. While the original goal had been to develop an electronic portfolio using the SCP as the enabling tool, it was disappointing to find the functionality of the system failed to support this goal.

The development of generic capabilities should not be isolated in one or two units, but should be embedded in all units of the GDLIS. This requires a cooperative and collaborative approach to teaching and learning on the part of all academic staff involved in the academic program. It requires a shift in the philosophical thinking of the GDLIS teaching team to openly acknowledge that their role as educators is to develop a holistic professional who can adequately perform in both the discipline content and generic capabilities.

\section{References}

AC Nielsen Research Services (2000). Employer satisfaction with graduate skills: research report. Retrieved January $15^{\text {th }}$, 2002 from the World Wide Web: http://www.detya.gov.au/archive/highered/eippubs/eip99-7/eip99_7pdf.pdf.

Atlay, M. \& Harris, R. (2000). An institutional approach to developing student's 'transferable' skills. Innovations in Education and Training International, 37(1): 76-84.

Bennett, N., Dunne, E., \& Carre, C. (2000). Skills development in higher education and employment. London: The Society for Research into Higher Education \& Open University Press.

Bowden, J., Hart, G., King, B., Trigwell, K., \& Watts, O. (2000). Generic capabilities of ATN university graduates. Retrieved November 15, 2002 from the World WideWeb: http://www.clt.uts.edu.au/ATN.grad.cap.project.index.html

Bridges, D. (1993). Transferable skills: a philosophical perspective. Studies in Higher Education, 18(1): 43-51.

Dearing Report. (1997). Higher education in the Learning Society. London: HMSO.

Dench, S. (1997). Changing skill needs: what makes people employable? Industrial and Commercial Training, 29(6), 190193.

De Vries, J. \& Rodkewich, P. M. (1997). Master reference librarians for a new age: a study of characteristics and traits. The Reference Librarian, 59: 203-214.

Down, C. Martin, E. Hager, P. \& Bricknell, L. (1999). Graduate attributes, key competence and judgements: exploring the links. Cornerstones: what do we value in higher education? HERDSA International Conference, Melbourne, 12-15 July 1999. Retrieved November 15, 2002 from the World Wide Web: http://www.herdsa.org.au/vic/cornerstones/authorframeset.html

Gush, J. (1997). Assessing the role of higher education in meeting the needs of the retail sector. Education and Training, 38(9), 4-12. 


\section{Technology and the Human Dimension}

Hargreaves, D. J., Murray, M., \& Allison, J. (2001 ). Developing a more holistic engineering graduate via a Student Capability Profile. Paper presented at the SEFI Annual Conference. Retrieved November 15, 2002 from the World Wide Web: http://www.sefi2001.dk/papers/pdf/19.pdf.

Katz, W. (2002). Introduction to reference work. ( $8^{\text {th }}$ ed.). Vol. 2. Boston: McGraw-Hill.

Kemp, I. J. \& Seagraves, L. (1995). Transferable skills - can higher education deliver? Studies in Higher Education, 20(3), 315-329.

Luca, J. Oliver, R., Omari, A., \& Dunbar, Al. (2001). Designing an on-line learning environment to support the development of generic skills: a case study. Neville Smythe (ed) E-Xplore 2001: a face-to-face odyssey. Proceedings from the apple university consortium conference, September 23-26 2001.Townsville Australia. Retrieved February 21, 2003 from the World Wide Web: http://auc.uow.edu.au/conf/conf01/downloads/AUC2001 Luca.pdf

Mayer, E. (1992). Putting general eduction to work: the key competencies. Melbourne: The Australian Education Council and Ministers for Vocational Education and Training.

Oliver, R. (1999). Exploring strategies for online teaching and learning. Distance Education, 20(2): 240 - .

Oliver, R., \& McLoughline, C. (2001). Exploring the practice and development of generic skills through web-based learning. Journal of Educational Multimedia and Hypermedia, 10(3): 207-226.

Queensland University of Technology (QUT). (2001). Policy C/1.3 Graduate capabilities. In: Manual of policies and proce-

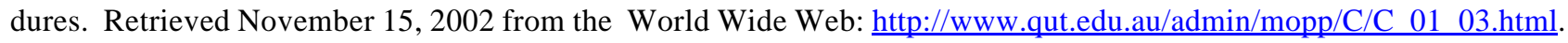

Woollard, A. (1995). Core skills and the idea of the graduate. Higher Education Quarterly, 49, 316-325. 